\title{
Overview of randomised trials of diuretics in pregnancy
}

\author{
RORY COLLINS, SALIM YUSUF, RICHARD PETO
}

\begin{abstract}
Over the past 20 years at least 11 randomised trials of the prevention with diuretics of pre-eclampsia and its sequelae have been undertaken. Nine of these were reviewed. Reliable data from the remaining two were not available. The nine reviewed had investigated a total of nearly 7000 people. Significant evidence of prevention of "pre-eclampsia" was overwhelming, even when oedema was not included as a diagnostic criterion. But as the definitions of pre-eclampsia that had been used depended heavily on increases in blood pressure this evidence may simply have reflected the well known ability of diuretics to reduce blood pressure. When the data on perinatal death were reviewed a little difference was seen in postnatal survival. The incidence of stillbirths was reduced by about one third with treatment, but, perhaps owing to small numbers (only 37 stillbirths), the difference was not significant. Thus these randomised trials failed to provide reliable evidence of either the presence or the absence of any worthwhile effects of treatment with diuretics on perinatal mortality.

The implications of this for current and future trials of $\beta$ blockers and other agents in the prevention of preeclampsia and its sequelae are that extremely large, ultra simple randomised trials are needed, of a size sufficient to permit direct assessment of the effects of treatment not on pre-eclampsia but on perinatal mortality itself. This may require the study of tens of thousands of pregnancies.
\end{abstract}

\footnotetext{
Clinical Trial Service Unit, Radcliffe Infirmary, Oxford OX2 6HE, and Department of Cardiovascular Medicine, John Radcliffe Hospital, Oxford

RORY COLLINS, MB, MSC, medical registrar

SALIM YUSUF, MRCP, DPHIL, medical registrar

RICHARD PETO, MSC, reader in cancer studies

Correspondence to: Dr R Collins, Clinical Trial Service Unit, Radcliffe Infirmary.
}

\section{Introduction}

During pregnancy various physiological abnormalities may be observed in the mother that regress when the pregnancy ends. These include oedema, hypertension, weight gain, hyperuricaemia, proteinuria, activation of coagulation factors, and increased turnover of platelets. Although the mechanisms by which pregnancy can induce such changes remain unclear, when some of these physiological abnormalities become severefor example, when blood pressure or proteinuria increase rapidly, leading in extreme cases to the development of fitsboth mother and child are subjected to an appreciably increased risk. Indeed, even when the changes are relatively moderate they are still associated with a moderate risk of perinatal death. Consequently, the term "pre-eclampsia" has been coined to describe such changes, and several agents have been used in the hope of reducing their degree of severity and consequently avoiding some of the associated perinatal (and maternal) deaths.

From 1960 on, small trials of diuretics and, more recently, other agents have been reported, ranging in size from under 100 up to a few thousand patients. As these studies have been too small to detect realistic effects on mortality they have generally concentrated on the effect of treatment on preeclampsia.

Unfortunately, although the term pre-eclampsia is widely used, the underlying mechanisms are so poorly understood that pre-eclampsia has been defined in a bewildering variety of ways, including various combinations of proteinuria, hyperuricaemia, hypertension, and even oedema and weight gain (although oedema and weight gain are not now considered to be of much independent prognostic significance). Of course, if pre-eclampsia is defined partly or wholly by hypertension, by definition any antihypertensive agents such as diuretics, methyldopa, or $\beta$ blockers must reduce its incidence. This is a matter of definition and not really one that should be addressed by clinical trials. Nevertheless, several trials have reported the ability of antihypertensive agents to reduce the incidence of pre-eclampsia when it was defined partly or wholly by hypertension, as though this question was an open one that needed to be settled by experimentation. Moreover, some trials have been so small that significance was not attained even for these predictable effects of treatment. Only if some treatment was being tested that did not have any known direct effect on the signs used to define pre-eclampsia would it be reasonable to undertake a trial of its effects on the incidence of 
pre-eclampsia as a preliminary investigation of its real importance. As, however, the signs of pre-eclampsia and, in particular, hypertension are correlated (though not necessarily directly) with an adverse fetal outcome, most trials have been of agents that are known to affect one or more of those signs. Consequently, the only informative end points in such trials are either signs, such as proteinuria, that are not already known to be affected by treatment or, preferably, as this is ultimately what matters, perinatal mortality. Perinatal mortality is, however, an extremely difficult outcome to study in clinical trials because so few pregnancies result in a stillbirth or neonatal death, and only a proportion even of these are associated with pre-eclampsia.

TABLE I-Characteristics of randomised controlled trials of diuretics in pregnancy

\begin{tabular}{|c|c|c|c|c|c|c|c|c|c|}
\hline \multirow[b]{2}{*}{ Study } & \multirow[b]{2}{*}{ Design } & \multirow[b]{2}{*}{ Criteria for entry } & \multirow{2}{*}{$\begin{array}{l}\text { Treatment } \\
\text { regimen }\end{array}$} & \multicolumn{3}{|c|}{ No followed up } & \multirow[b]{2}{*}{ No withdrawn } & \multirow[b]{2}{*}{$\begin{array}{l}\text { Primary } \\
\text { end points }\end{array}$} & \multirow[b]{2}{*}{$\begin{array}{l}\text { Definition of } \\
\text { pre-eclampsia }\end{array}$} \\
\hline & & & & Total & $\begin{array}{l}\text { Diuretic } \\
\text { treated } \\
\text { patients }\end{array}$ & $\begin{array}{l}\text { Control } \\
\text { patients }\end{array}$ & & & \\
\hline Zuspan et al ${ }^{1}$ & Double blind & $\begin{array}{l}\text { Rapid or excessive } \\
\text { weight gain. } \\
\text { Presence of oedema }\end{array}$ & $\begin{array}{l}\text { Hydrochlorothiazide } \\
100 \mathrm{mg} / \text { day } \times 4 \text { days } \\
\text { or } 100 \mathrm{mg} / \text { day } \times 2 \\
\text { days plus } 50 \mathrm{mg} / \text { day } \\
\times 5 \text { days, or } \\
\text { dihydrotrichlorothia- } \\
\text { zide } 10 \mathrm{mg} / \text { day } \times \\
2 \text { days plus } 5 \mathrm{mg} / \\
\text { day } \times 5 \text { days }\end{array}$ & 336 & 193 & 143 & 154 & Weight gain & $\begin{array}{l}\text { Not used as } \\
\text { endpoint }\end{array}$ \\
\hline $\begin{array}{l}\text { Weseley and } \\
\text { Douglas }^{2}\end{array}$ & Double blind & $\begin{array}{l}\text { Second or third } \\
\text { trimester with } \\
\geqslant 2 \cdot 3 \mathrm{~kg} \text { weight gain } \\
\text { in two weeks or } \\
\text { increasing oedema of } \\
\text { extremities }\end{array}$ & $\begin{array}{l}\text { Chlorothiazide } \\
100 \mathrm{mg} / \mathrm{day} \text { until } \\
\text { delivery } \\
\text { f }\end{array}$ & 267 & 131 & 136 & Nil & $\begin{array}{l}\text { Pre-eclampsia } \\
\text { Proteinuric } \\
\text { pre-eclampsia } \\
\text { Stillbirth } \\
\text { Neonatal death }\end{array}$ & CMW* \\
\hline Flowers $e t a l^{3}$ & Double blind & $\begin{array}{l}<30 \text { th week. } \\
\text { Mean }=19 \text { th week }\end{array}$ & $\begin{array}{l}\text { Chlorothiazide } 250 \\
\mathrm{mg} / \text { day, } 500 \mathrm{mg} / \\
\text { day, or } 750 \mathrm{mg} / \mathrm{day} \\
\text { until delivery }\end{array}$ & $\begin{array}{l}519 \\
(445) \ddagger\end{array}$ & $\begin{array}{l}385 \\
(335) \ddagger\end{array}$ & $(134) \ddagger$ & $\begin{array}{l}\text { No details on } \\
\text { perinatal deaths } \\
\text { for } 50 \text { treated } \\
\text { patients and } 24 \\
\text { controls }\end{array}$ & $\begin{array}{l}\text { Pre-eclampsia } \\
\text { Stillbirth } \\
\text { Neonatal death }\end{array}$ & $\begin{array}{l}\text { Systolic blood } \\
\text { pressure } \geqslant 140 \\
\text { mm Hg or } \\
\text { diastolic blood } \\
\text { pressure } \\
\geqslant 90 \mathrm{~mm} \mathrm{Hg} \text { in } \\
\text { previously } \\
\text { normotensive } \\
\text { patient, or } \\
\text { appreciable } \\
\text { change in } \\
\text { hypertensive } \\
\text { patient }\end{array}$ \\
\hline Menzies" & $\begin{array}{l}\text { Open control: } \\
\text { phenobarbi- } \\
\text { tone }\end{array}$ & $\begin{array}{l}\text { 24th week with } \\
\text { systolic blood } \\
\text { pressure } \geqslant 140 \\
\text { mm Hg, diastolic } \\
\text { blood pressure } \geqslant 85 \\
\text { mm Hg, or ankle } \\
\text { oedema, or weight } \\
\text { gain } \geqslant 1.8 \text { kg in } \\
\text { any two weeks } \\
\text { after } 24 \text { th week }\end{array}$ & $\begin{array}{l}\text { Chlorothiazide } 100 \\
\text { mg/day plus } \\
\text { potassium chloride } \\
2 \text { g/day for a week } \\
\text { and continued if } \\
\text { indications persist } \\
\text { or return }\end{array}$ & 105 & 57 & 48 & Nil & $\begin{array}{l}\text { Pre-eclampsia } \\
\text { requiring } \\
\text { admission } \\
\text { Proteinuric } \\
\text { pre-eclampsia } \\
\text { Stillbirth } \\
\text { Neonatal death }\end{array}$ & $\begin{array}{l}\text { Systolic blood } \\
\text { pressure }>145 \\
\text { mm Hg or } \\
\text { diastolic blood } \\
\text { pressure }>85 \\
\text { mm Hg or } \\
\text { weight gain } \\
>0.9 \mathrm{~kg} \text { in } \\
\text { week of treat- } \\
\text { ment; or non- } \\
\text { infective } \\
\text { albuminuria; or } \\
\text { substantial } \\
\text { increase in } \\
\text { oedema }\end{array}$ \\
\hline Fallis et $a l^{5}$ & Double blind & $\begin{array}{l}\text { All primigravid. } \\
\text { Expected date of } \\
\text { delivery }>13 \text { weeks. } \\
\text { Diastolic blood } \\
\text { pressure }<90 \mathrm{~mm} \\
\text { Hg. Free of oedema } \\
\text { and proteinuria }\end{array}$ & $\begin{array}{l}\text { Hydrochlorothiazide } \\
50 \mathrm{mg} / \text { day until } \\
\text { delivery }\end{array}$ & $\begin{array}{c}78 \\
(74) \ddagger\end{array}$ & $\begin{array}{l}38 \\
(34) \ddagger\end{array}$ & $\begin{array}{c}40 \\
(40) \ddagger\end{array}$ & $\begin{array}{l}\text { Two lost to follow } \\
\text { up. No details } \\
\text { on perinatal } \\
\text { deaths for four } \\
\text { treated patients }\end{array}$ & $\begin{array}{l}\text { Pre-eclampsia } \\
\text { Stillbirth } \\
\text { Neonatal death }\end{array}$ & $\mathrm{CMW} *$ \\
\hline $\begin{array}{l}\text { Cuadros and } \\
\text { Tatum }\end{array}$ & $\begin{array}{l}\text { Double blind; } \\
\text { "rotational" } \\
\text { allocation }\end{array}$ & $\geqslant 30$ weeks & $\begin{array}{l}\text { Bendroflumethiazide } \\
5 \mathrm{mg} / \text { day until } \\
\text { delivery }\end{array}$ & 1771 & 1011 & 760 & $\mathrm{Nil}$ & $\begin{array}{l}\text { Pre-eclampsia } \\
\text { Proteinuria } \\
\text { Eclampsia } \\
\text { Stillbirth } \\
\text { Neonatal death }\end{array}$ & Not available \\
\hline $\begin{array}{l}\text { Landesman } \\
\text { et } a l^{7}\end{array}$ & Double blind & 28th to 32 nd week & $\begin{array}{l}\text { Chlorthalidone } \\
50 \mathrm{mg} / \text { day until } \\
\text { delivery }\end{array}$ & 2706 & 1370 & 1336 & 193 & $\begin{array}{l}\text { Pre-eclampsia } \\
\text { Proteinuric } \\
\text { pre-eclampsia } \\
\text { Stillbirth plus } \\
\text { neonatal death }\end{array}$ & $\mathrm{CMW}^{*}$ \\
\hline $\begin{array}{l}\text { Finnerty and } \\
\text { Bepko }^{8}\end{array}$ & $\begin{array}{l}\text { Open } \\
\text { "alternate" } \\
\text { allocation }\end{array}$ & $\begin{array}{l}<17 \text { years. No } \\
\text { history of renal } \\
\text { disease or findings } \\
\text { of oedema, increased } \\
\text { blood pressure, or } \\
\text { albuminuria }\end{array}$ & $\begin{array}{l}\text { Thiazide diuretics } \\
\text { until delivery }\end{array}$ & 3083 & 1340 & 1743 & $\begin{array}{l}201 \text { treated patients } \\
\text { transferred to } \\
\text { control group for } \\
\text { "non-compliance" }\end{array}$ & $\begin{array}{l}\text { Pre-eclampsia } \\
\text { Stillbirth } \\
\text { Neonatal death }\end{array}$ & $\begin{array}{l}\text { Oedema of } \\
\text { periorbital area } \\
\text { and hands; } \\
-10 \% \text { rise in } \\
\text { mean arterial } \\
\text { pressure or } \\
\text { non-infective } \\
\text { albuminuria }\end{array}$ \\
\hline Kraus $e t a l^{\circ}$ & Double blind & $\begin{array}{l}<24 \text { th week without } \\
\text { idiopathic } \\
\text { thrombocytopenic } \\
\text { purpura, severe } \\
\text { diabetes, or sickle } \\
\text { cell anaemia }\end{array}$ & $\begin{array}{l}\text { Hydrochlorothiazide } \\
50 \mathrm{mg} / \text { day until } \\
\text { delivery }\end{array}$ & 1030 & 506 & 524 & $\begin{array}{l}62 \text { treated patients, } \\
47 \text { controls }\end{array}$ & $\begin{array}{l}\text { Blood pressure } \\
\text { Pre-eclampsia } \\
\text { Stillbirth } \\
\text { Neonatal death }\end{array}$ & $\mathrm{CMW}^{*}$ \\
\hline $\begin{array}{l}\text { Tervila and } \\
\text { Vartiainen }^{10}\end{array}$ & Single blind & $\begin{array}{c}\text { Primigravid }>16 \text { th } \\
\text { week }\end{array}$ & $\begin{array}{l}\text { Chlorthalidone } \\
50 \mathrm{mg} / \text { day until } \\
\text { delivery }\end{array}$ & 211 & 108 & 103 & $\begin{array}{l}15 \text { treated patients, } \\
19 \text { controls } \\
\text { (including two } \\
\text { abortions) }\end{array}$ & $\begin{array}{l}\text { Oedema } \\
\text { Proteinuric } \\
\text { pre-eclampsia } \\
\text { Blood pressure } \\
\text { Weight gain }\end{array}$ & $\begin{array}{l}\text { Proteinuria } \\
\geqslant 0.4 \mathrm{~g} / \mathrm{d} \\
\text { Blood pressure. } \\
>140 / 90 \mathrm{~mm} \\
\mathrm{Hg}\end{array}$ \\
\hline $\begin{array}{l}\text { Campbell } \\
\text { and Mac- } \\
\text { Gillivray }{ }^{112}\end{array}$ & $\begin{array}{l}\text { Open } \\
\text { Two controls: } \\
2 \text { MJ diet } \\
\text { Normal care }\end{array}$ & $\begin{array}{l}\text { Primigravid with } \\
\text { weight gain } \\
>0.6 \mathrm{~kg} / \text { week } \\
\text { 20th to } 30 \text { th week }\end{array}$ & $\begin{array}{l}\text { Cyclopenthiazide } \\
0.5 \mathrm{mg} / \mathrm{day} \text { plus } \\
\text { potassium } 1.2 \mathrm{~g} / \\
\text { day, or spironolactone, } \\
\text { or clopamide- } \mathrm{K}\end{array}$ & 255 & 153 & 102 & Nil & $\begin{array}{l}\text { Pre-eclampsia } \\
\text { Proteinuric } \\
\text { pre-eclampsia } \\
\text { Birth weight }\end{array}$ & Nelson $\dagger$ \\
\hline
\end{tabular}

Definitions of pre-eclampsia: ${ }^{*} \mathrm{CMW}=$ Committee on Maternal Welfare: increase in systolic blood pressure $\geqslant 30 \mathrm{~mm} \mathrm{Hg}$ or systolic blond pressure $\geqslant 140 \mathrm{~mm} \mathrm{Hg}$, or increase in diastolic blood pressure $\geqslant 15 \mathrm{~mm} \mathrm{Hg}$ or diastolic blood pressure $\geqslant 90 \mathrm{~mm}$ Hg, with or without proteinuria or oedema after 24 th week. ${ }^{33}+\mathrm{Nelson}$ : Diastolic blood pressure $\geqslant 90 \mathrm{~mm} \mathrm{Hg}$ after 26 th week, with proteinuria (
$\ddagger$ Numbers of patients with follow up for perinatal deaths.

Conversion: SI to traditional units-Energy: $1 \mathrm{MJ} \approx 240 \mathrm{kcal}$. 
Indeed, unless a group of women at extraordinarily high risk can be identified for study, trials among tens of thousands of women may be needed to pick up the kind of moderate improvements that can realistically be hoped for.

\section{REVIEW OF TRIALS OF DIURETICS}

Since 1960 over 10000 women have been studied in a total of 11 published randomised controlled trials of the use of diuretics in pregnancy (table I). ${ }^{1-12}$ It is now generally believed that: (1) the randomised trials have shown that diuretics have no material effect on perinatal mortality ${ }^{13}{ }^{14} ;$ (2) the trials that showed some reduction in the incidence of pre-eclampsia ${ }^{3-9}$ did so solely because oedema (which is cleared by diuretics) was included in the definitions ${ }^{13}$; and (3) the natural history of progressive pre-eclampsia includes depletion of plasma volume, ${ }^{13}$ aggravation of which by diuretics is thought to be potentially hazardous for both mother and fetus. ${ }^{15} 16$ We examined to what extent, if at all, the results of the randomised trials supported these beliefs.

In the absence of treatment, the increased perinatal mortality associated with pre-eclampsia is largely confined to those women with severe pre-eclampsia as defined, for example, by a diastolic pressure of $110 \mathrm{~mm} \mathrm{Hg}$ or more, or by proteinuria with a diastolic pressure of $90 \mathrm{~mm} \mathrm{Hg}$ or more, or by frank eclampsia. ${ }^{17}$ In the presence of antihypertensive treatment, however, the incidence of these signs will be altered, and although studies of the effects of antihypertensive treatment on proteinuria or hyperuricaemia would be of some interest, the real need is to assess correctly the effect of treatment on stillbirths and neonatal deaths. Individually, however, the trials of diuretics that have been conducted to date have been far too small to provide reliable estimates of the type of moderate, but still clinically important, effects that could reasonably be expected on these end points. For example, in England and Wales, where the perinatal mortality rate was $11 \cdot 8 / 1000$ total births in $1981,{ }^{18}$ reliable assessment even of a halving of this perinatal mortality rate might well require the randomisation of about 10000 women at normal risk or of several thousand women at high risk. In the absence of trials of this size, however, some useful estimates of the likely effects of diuretics on serious but rare end points such as these may still be obtained by combining the information (irrespective of the results) from all the randomised controlled trials, as is done when the results from individual centres are combined in multicentre trials. Such an overview does not, of course, implicitly assume that the selection criteria, treatment regimens, or definitions of outcome are similar in different trials, for they are not: it assumes merely that patients in one randomised trial can be compared unbiasedly with other patients in the same study.

In addition to the general view that diuretics are likely to be ineffective there have been reports of side effects with their use in pregnancy, including hypokalaemia, ${ }^{91019}$ diabetogenic like changes in carbohydrate metabolism, ${ }^{20}$ and the masking of hyperuricaemia associated with pre-eclampsia. ${ }^{21}$ Much less commonly, neonatal thrombocytopenia and jaundice, ${ }^{22-24}$ maternal pancreatitis, ${ }^{25-27}$ hyponatraemia, and exacerbation of renal insufficiency ${ }^{28}$ have been said to have occurred with the thiazides. As, however, the evidence for these side effects is based on highly selected case reports it does not provide any reliable indication of whatever increase in risk may be associated with the use of diuretics in pregnancy.

This study therefore had two aims. Firstly, to determine whether the overall evidence from all the randomised trials of diuretics in pregnancy supports the current belief that such treatment has no beneficial effect on the incidence of serious end points such as proteinuria or, preferably, perinatal deaths. Secondly, to discuss the errors of interpretation and design of the trials of diuretics that need to be avoided in the current trials of other agents if these are to yield reliable information about the likely effects of treatment. They may otherwise yield either unreliable claims of benefit based on the significance of reductions in the incidence of pre-eclampsia (for which, as has been noted, no trials are needed if the agent being used is known to affect one or more of the signs used to define preeclampsia) or unreliable claims of no benefit based on the non-significance of the effect of treatment on perinatal mortality in trials that are too small to show reliably the moderate effects that could reasonably be expected.

\section{Method}

\section{ACQUISITION OF DATA}

We sought all published randomised controlled trials of diuretics in pregnancy by reviewing reference lists in relevant papers, conducting manual and computer (Medline) searches of published articles, and discussing the subject with colleagues and the authors of studies already identified. Supplementary details of design or outcome were requested from the principal investigators in most instances-for example, if some randomised patients had been excluded from the reported analysis or if numbers of stillbirths, neonatal deaths, or occurrences of eclampsia were not reported. As many of the studies, however, were conducted 10 or 20 years ago, complete information on all randomised patients could not be obtained in some studies. In those studies in which several of the randomised patients were subsequently excluded, therefore, the possibility of some bias remained. Such biases appeared likely to be severe, however, only in the study of Finnerty and Bepko, in which about $13 \%$ of the patients originally allocated to the treatment group were transferred to the control group for the purposes of analysis owing to their non-compliance and in which the treated patients, but not the controls, were screened for bacteriuria with subsequent exclusion of any patients in whom it was identified. ${ }^{8}$ Data that could rectify these biases no longer appear to exist; we therefore excluded this trial from all "pooled" analyses. The study of Zuspan et al was also excluded as details on pre-eclampsia, stillbirths, and neonatal deaths were not provided and are no longer available. ${ }^{1}$

\section{STATISTICAL METHODS}

The fundamental idea in our overview of the results of randomised trials was that, for each separate trial, the patients allocated to treatment and those allocated to control should be compared only with each other, and not with patients in any other trial. From this comparison, a numerical measure (O-E, see below) of the difference in outcome between these two groups was calculated. $\mathrm{O}-\mathrm{E}$ was the number of patients allocated to treatment who were observed to develop a particular unfavourable event minus the number that would have been expected to have done so on the basis of the combined actual experience of the treated and control patients in that trial. If, in a particular trial, treatment did not have a net effect O-E could equally well be positive or negative and would differ only randomly from zero. On the other hand, if, on balance, treatment prevented a proportion of events O-E would tend to be negative. This would obviously be the case in a trial in which all the patients, without exception, received their allocated treatment. It should also be the case even if some patients deviated from their allocation, for most of those allocated to treatment would have undergone treatment and most of the controls would not. (For reasons discussed by Peto et al, section 13,29 our analyses are based not on the comparison of patients who actually received treatment with patients who did not but rather on the comparison of patients allocated to treatment and patients not.)

\section{COMBINATION OF INFORMATION FROM MANY TRIALS}

In any one trial, however, the play of chance might have exaggerated or obscured the tendency of O-E to be negative, especially if the trial was small or treatment had only a moderate effect. If, however, $\mathrm{O}-\mathrm{E}$ were calculated separately for each trial and these O-E values, one from each trial, finally added up to yield a grand total (GT), these separate tendencies would be likely to reinforce each other, making GT even more likely to be negative. Conversely, if treatment were without any net effect on outcome each value for O-E would differ only randomly from zero and, therefore, so too would their sum, as long as all randomised trial results were used, without any data dependent 
exceptions. The variance (VT) of the grand total would, moreover, then simply be the sum of the variances of the separate O-E values, and these are easily calculated by standard formulas. (Formally, consider a trial in which there are $\mathrm{n}$ randomised patients, of whom $\mathrm{t}$ are allocated to treatment and c are allocated to serve as controls, and in which d patients suffer a particular unfavourable event. If treatment had no effect on outcome $O-E$ (where $E=t d / n$ ) would have zero expectation and variance $\mathrm{E} c(1-\mathrm{d} / \mathrm{n}) /(\mathrm{n}-1)$. The standard error of the grand total would therefore be the square root of this variance. Throughout, tests of significance (and confidence limits, see below) exploit the fact that the more trials were combined in this way, the more the grand total would tend to have an approximately normal distribution. (Thus, for example, if $\mathrm{GT} \simeq-1.96 \sqrt{\mathrm{VT}}$, then the two tailed significance level, $2 \mathrm{p}$, would be approximately 0.05 .)

Examination of the grand total assumed that all data from all randomised trials were included without any material bias, such as the withdrawal after randomisation of patients at high risk from the treated group or the unavailability of trials that were not published because they were negative. It did not assume, however, that patients in one trial could be compared directly with patients in another (for it was based solely on the comparison of patients receiving treatment in a particular trial with the controls in the same trial), so that differences in criteria for inclusion of patients or in definitions of end points did not materially bias the test of the null hypothesis. Nor did it assume that, if there were any real effects of treatment, these were necessarily the same in the different trials (see appendix).

\section{Results}

PRE-ECLAMPSIA

As the most commonly used indicators of pre-eclampsia are, or were, moderate hypertension or oedema, or both, and as diuretics are known to reduce both of these in normal (non-pregnant) subjects by mechanisms that presumably operate fairly similarly in pregnant subjects, it would be remarkable if diuretics did not reduce the incidence of pre-eclampsia. Yet in nearly half ${ }^{2-12}$ of the nine trials that table II lists such an effect was not significantly apparent, presumably because of a combination of the effects of inadequate size and the play of chance. When, however, the nine separate O-E values, one for each trial, were added up their grand total $(-52 \cdot 8$, with variance 129.0 and, hence, standard error 11.4 ) was more than four standard errors below zero, which is highly significant. Despite the reductions in risk being definitely (fig 1) greater in some trials than in others, it is not medically plausible that the true effect would have been zero in any of the trials. Hence the contrast between the high degree of significance of the results of this overview and the lack of significance of the results of four of the nine separate trials illustrates how useful a proper overview of many trials can be as long as, like here, it does not implicitly assume that all trials are similar.

To illustrate that this apparent reduction in the risk of developing pre-eclampsia did not just entail clearance of oedema (which is now not generally considered to be of much relevance to pre-

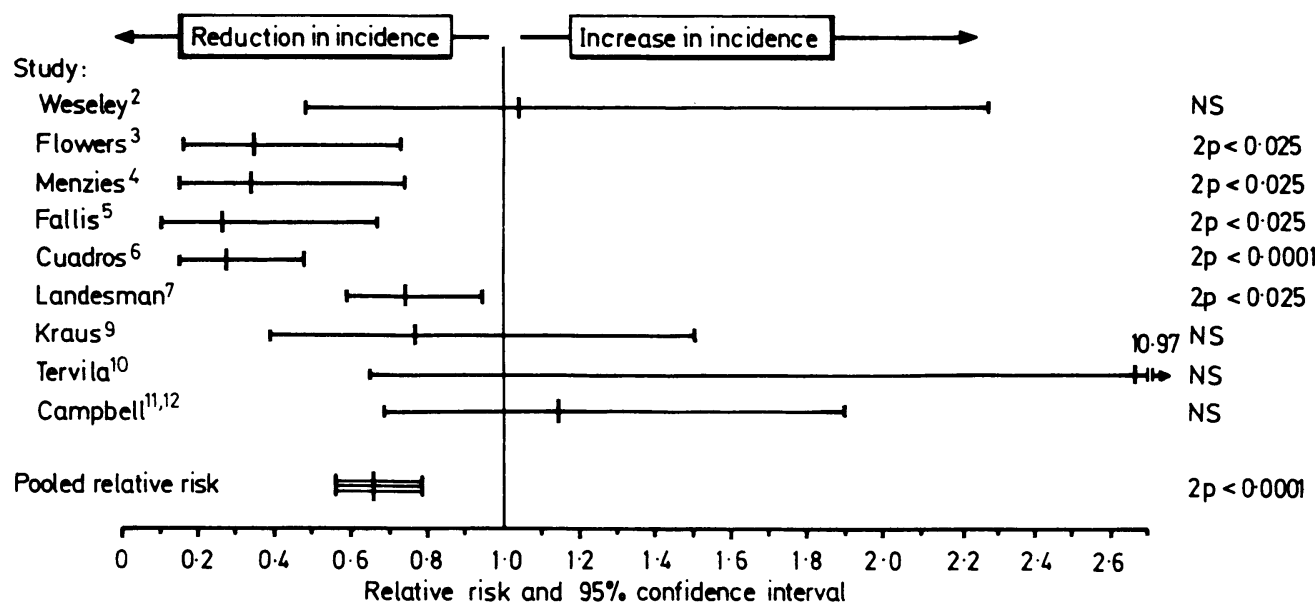

FIG 1 -Relative risk of pre-eclampsia (as defined in table $\mathrm{I}$ ) in individual randomised controlled trials of diuretics, with "pooled" relative risk. Each relative risk is accompanied by approximate $95 \%$ confidence limits. Test for heterogeneity: $x^{2}=29 \cdot 3 ; 2 p<0 \cdot 001$

TABLE II-Results of randomised controlled trials of effects of diuretics on pre-eclampsia

\begin{tabular}{|c|c|c|c|c|c|c|c|c|c|c|c|}
\hline \multirow{3}{*}{ Study } & \multicolumn{2}{|c|}{$\begin{array}{l}\text { No of patients } \\
\text { followed up }\end{array}$} & \multicolumn{4}{|c|}{ Any form of pre-eclampsia } & \multicolumn{5}{|c|}{ Severe or proteinuric pre-eclampsia } \\
\hline & \multirow{2}{*}{ Treated } & \multirow{2}{*}{ Control } & \multirow{2}{*}{$\begin{array}{c}\text { No in } \\
\text { treated } \\
\text { patients }\end{array}$} & \multirow{2}{*}{$\begin{array}{l}\text { No in } \\
\text { controls }\end{array}$} & \multicolumn{2}{|c|}{ Treated patients } & \multirow{2}{*}{ Definition } & \multirow{2}{*}{$\begin{array}{c}\text { No in } \\
\text { treated } \\
\text { patients }\end{array}$} & \multirow{2}{*}{$\begin{array}{l}\text { No in } \\
\text { controls }\end{array}$} & \multicolumn{2}{|c|}{ Treated patients } \\
\hline & & & & & $\mathrm{O}^{+}+$ & Variance & & & & O-E & Variance \\
\hline Weseley and Douglas ${ }^{2 *}$ & 131 & 136 & 14 & 14 & +0.3 & $6 \cdot 3$ & Severe & 3 & 2 & $+0 \cdot 6$ & $1 \cdot 2$ \\
\hline $\begin{array}{l}\text { Flowers et } a l^{*} \\
\text { Menzies }\end{array}$ & $\begin{array}{r}385 \\
57\end{array}$ & $\begin{array}{r}134 \\
48\end{array}$ & $\begin{array}{l}21 \\
14\end{array}$ & $\begin{array}{l}17 \\
24\end{array}$ & $\begin{array}{l}-7 \cdot 2 \\
-6.6\end{array}$ & $\begin{array}{l}6 \cdot 8 \\
6 \cdot 1\end{array}$ & & 3 & 5 & $-1 \cdot 3$ & 1.9 \\
\hline $\begin{array}{l}\text { Fallis et al } l^{5 *} \\
\text { Cuadros and Tatum } \\
\text { Landesman } \text { et }^{6} l^{7 *}\end{array}$ & $\begin{array}{r}38 \\
1011 \\
1370\end{array}$ & $\begin{array}{r}40 \\
760 \\
1336\end{array}$ & $\begin{array}{r}6 \\
12 \\
138\end{array}$ & $\begin{array}{r}18 \\
35 \\
175\end{array}$ & $\begin{array}{r}-5 \cdot 7 \\
-14.8 \\
-20.5\end{array}$ & $\begin{array}{r}4 \cdot 2 \\
11 \cdot 2 \\
69 \cdot 2\end{array}$ & $\begin{array}{l}\text { Not available } \\
\text { Eclampsia } \\
\text { Severe } \\
\text { pre-eclampsia } \\
\text { ore celampsia }\end{array}$ & $\begin{array}{r}1 \\
20\end{array}$ & $\begin{array}{r}4 \\
23\end{array}$ & $\begin{array}{l}-1 \cdot 9 \\
-1 \cdot 8\end{array}$ & $\begin{array}{l}1 \cdot 2 \\
10 \cdot 6\end{array}$ \\
\hline $\begin{array}{l}\text { Kraus et al }{ }^{* *} \\
\text { Tervila and Vartiainen } \\
\text { Campbell and } \\
\text { MacGillivray } \\
\end{array}$ & $\begin{array}{l}506 \\
108 \\
153\end{array}$ & $\begin{array}{l}524 \\
103 \\
102\end{array}$ & $\begin{array}{r}15 \\
6 \\
65\end{array}$ & $\begin{array}{r}20 \\
2 \\
40\end{array}$ & $\begin{array}{l}-2 \cdot 2 \\
+1 \cdot 9 \\
+2 \cdot 0\end{array}$ & $\begin{array}{r}8 \cdot 5 \\
1.9 \\
14 \cdot 9\end{array}$ & $\begin{array}{l}\text { Not available } \\
\text { Proteinuria } \\
\text { Proteinuric } \\
\text { pre-eclampsia }\end{array}$ & $\begin{array}{r}6 \\
19\end{array}$ & $\frac{2}{15}$ & $\begin{array}{l}+1 \cdot 9 \\
-1 \cdot 4\end{array}$ & $\begin{array}{l}1 \cdot 9 \\
7 \cdot 1\end{array}$ \\
\hline \multirow{2}{*}{$\begin{array}{l}\text { Overall: } \\
\text { Any form of pre-eclampsia } \\
\text { Pre-eclampsia, oedema not a } \\
\text { diagnostic criterion } \\
\text { Severe or proteinuric } \\
\text { pre-eclampsia } \\
\end{array}$} & 3759 & 3183 & \multirow{2}{*}{$\begin{array}{l}291 \\
(7 \cdot 7 \%) \\
265 \% \\
(9 \cdot 8 \%)\end{array}$} & \multirow{2}{*}{$\begin{array}{l}345 \\
(10 \cdot 8 \% \\
286 \\
\left(12 \cdot 0^{\circ}{ }_{0}\right)\end{array}$} & $-52 \cdot 8$ & $129 \cdot 0$ & & & & & \\
\hline & $\begin{array}{l}2691 \\
2830\end{array}$ & $\begin{array}{l}2375 \\
2485\end{array}$ & & & $-31 \cdot 4$ & 111.7 & & $\begin{array}{c}52 \\
(1.8 \%)\end{array}$ & $\begin{array}{c}51 \\
(2 \cdot 1 \%)\end{array}$ & $-3 \cdot 9$ & $23 \cdot 9$ \\
\hline \multirow{2}{*}{\multicolumn{3}{|c|}{$\begin{array}{l}\text { Any form of pre-eclampsia } \\
\text { Pre-eclampsia, oedema not a diagnostic criterion } \\
\text { Severe or proteinuric pre-eclampsia }\end{array}$}} & \multicolumn{2}{|c|}{ "Pooled" relative risk } & \multicolumn{3}{|c|}{$95 \%$ confidence interval } & \multicolumn{2}{|c|}{ Test for heterogeneity } & & \\
\hline & & & \multicolumn{2}{|c|}{$\begin{array}{l}0.66 \\
0.75 \\
0.85\end{array}$} & \multicolumn{3}{|c|}{$\begin{array}{l}0.56,0.79(2 \mathrm{p}<0.0001) \\
0.63,0.91(2 \mathrm{p}<0.005) \\
0.57,1.27(\mathrm{NS})\end{array}$} & $\begin{array}{l}x^{2}{ }^{2}=29 \cdot 3 \\
x_{6}^{2}=15 \cdot 3 \\
x^{2}=5 \cdot 8\end{array}$ & $\begin{array}{l}3 p<0 \cdot 0005) \\
2 \mathrm{p}<0 \cdot 025) \\
\mathrm{NS})\end{array}$ & & \\
\hline
\end{tabular}

* Oedema not a diagnostic criterion.

tThe number of patients allocated to treatment who were observed to develop a particular unfavourable event minus the number that would have been expected to do so if treatment had no effect. 
eclampsia), those trials in which oedema was not among the diagnostic criteria have been marked with an asterisk in table II, and a separate overview of these confirmed that there was still, as expected, a massively significant effect of treatment. This must, however, be at least in part because of the effects of diuretic treatment on blood pressure. To see whether any effect remained when attention was restricted to criteria, such as proteinuria, that are not as directly affected by diuretics as blood pressure is, the data on more stringent measures of pre-eclampsia were, if available, listed separately to the right in table II. No reliable synthesis of these results is possible, however, because: data from three trials were completely unavailable ${ }^{35}{ }^{9}$; the available data from three more trials related to pre-eclampsia, albeit of a more severe type, that still depended importantly on blood pressure ${ }^{2}{ }^{111}$; and the number of affected patients available for study (103 in all) was inadequate for reliable inference and would have become still more so (only 21 remaining) if end points that depended directly on blood pressure had been ignored.

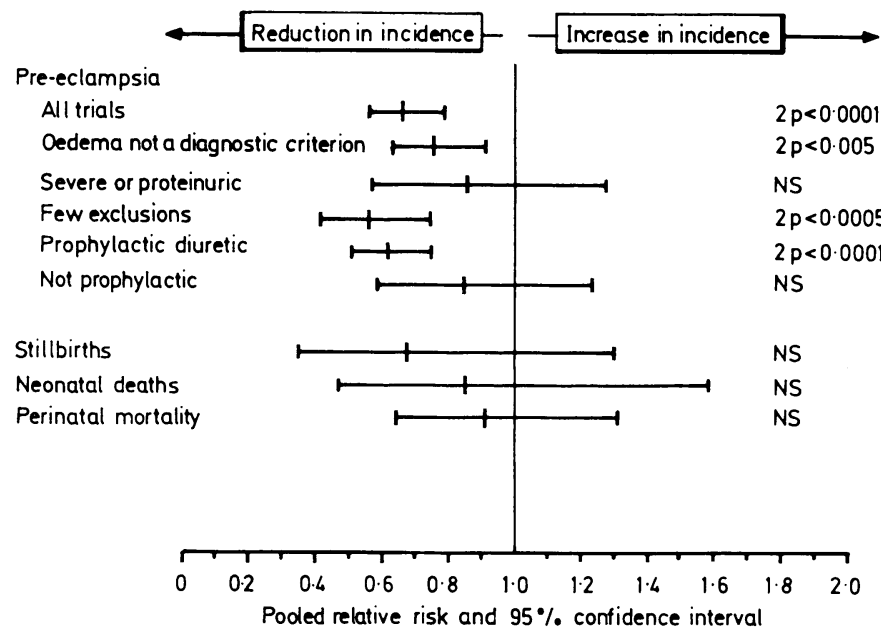

FIG 2-"Pooled" relative risk of pre-eclampsia and perinatal death in randomised controlled trials of diuretics, with approximate $95 \%$ confidence limits.

For what they are worth, figure 2 summarises the odds ratios from analyses of various subsets of these data. The real message is, however, clear: in trying to discover what the results of these nine trials implied about the value of diuretics in pregnancy we were forced to concentrate our attention chiefly on perinatal mortality, and the same will be the case when, a few years hence, a sufficient number of trials of $\beta$ blockers become available for review.
TABLE IV-Reported side effects in randomised controlled trials of diuretics in pregnancy

\begin{tabular}{|c|c|c|c|c|c|}
\hline \multirow[b]{2}{*}{ Side effect } & \multirow[b]{2}{*}{ Study } & \multicolumn{2}{|c|}{ Treated patients } & \multicolumn{2}{|c|}{ Controls } \\
\hline & & No & $\begin{array}{l}\text { No } \\
\text { with } \\
\text { side } \\
\text { effect }\end{array}$ & No & $\begin{array}{l}\text { No } \\
\text { with } \\
\text { side } \\
\text { effect }\end{array}$ \\
\hline $\begin{array}{l}\text { Thrombocytopenic } \\
\text { purpura } \\
\text { Jaundice }\end{array}$ & $\begin{array}{l}\text { Menzies }{ }^{4} \quad \text { Neonatal } \\
\text { Kraus et al }{ }^{9} \\
\text { Flowers et al }{ }^{324} \\
\text { (Random selection } \\
\text { from complete } \\
\text { study) }\end{array}$ & $\begin{array}{r}57 \\
506 \\
70\end{array}$ & $\begin{array}{r}1 \\
0 \\
13\end{array}$ & $\begin{array}{r}48 \\
524 \\
40\end{array}$ & $\begin{array}{r}0 \\
0 \\
31\end{array}$ \\
\hline \multirow[t]{3}{*}{$\begin{array}{l}\text { Pancreatitis } \\
\text { Hypokalaemia or } \\
\text { hyponatraemia, or } \\
\text { both }\end{array}$} & \multicolumn{5}{|c|}{$\begin{array}{l}\text { Maternal } \\
\text { No cases reported in randomised controlled trials } \\
\text { Flowers } \text { et }^{3} l^{3} \\
\quad \text { No cases in } 10 \% \text { sample and all } \\
\quad \text { patients complaining of weakness }\end{array}$} \\
\hline & $\left.\begin{array}{l}\text { Menzies" } \\
\text { Cuadros and Tatum } \\
\text { Landesman et al } \\
\text { Campbell and } \\
\text { MacGillivray } \\
1112\end{array}\right\}$ & \multicolumn{4}{|c|}{$\begin{array}{l}\text { No significant difference in serum } \\
\text { sodium or potassium } \\
\text { concentrations }\end{array}$} \\
\hline & $\begin{array}{l}\text { Kraus et al } \\
\quad \text { Potassium } \\
\text { concentration } \\
<3.5 \mathrm{mmol}(\mathrm{mEq}) / \mathrm{l}) \\
\text { Tervila and Vartiainen } \\
\quad \text { (Potassium } \\
\text { concentration } \\
<2.7 \mathrm{mmol} / \mathrm{l})\end{array}$ & 108 & 80 & 524 & 37 \\
\hline
\end{tabular}

\section{PERINATAL MORTALITY}

An overview of the data on perinatal mortality (generally considered in these trials to be stillbirths plus neonatal deaths during the first month) suggested a roughly $10 \%$ reduction from $1.9 \%(60 / 3159)$ to $1.7 \%(63 / 3705)$, which was not significant despite the randomisation of about 7000 women. (Altogether $2 \cdot 7$ fewer perinatal deaths than expected were observed among patients allocated to receive treatment, while 2.7 more than expected were observed among the controls, suggesting prevention of about five perinatal deaths: formally, the "pooled" relative risk was 0.91 , with a $95 \%$ confidence interval of 0.64 to 1.31 ; not significant.) Showing such a moderate reduction in the perinatal mortality rate would, however, be a formidable undertaking (particularly as the perinatal mortality rate is now about $1 \%{ }^{18}$ ) requiring the randomisation of more than 50000 women.

The data suggested that any real benefit might be concentrated chiefly in the avoidance of stillbirths rather than of neonatal deaths (table III). Although this is merely a hypothesis suggested by the data, and as such is even less reliable than the formal confidence intervals implied, it would be more practicable to test it prospectively. The apparent reduction in the incidence of stillbirths was roughly $30 \%$, but not surprisingly this result was not significant as it was based on only 37 stillbirths in 4000 pregnancies. If diuretics truly reduced stillbirths by $30 \%$, a trial in about 20000 women might be needed to show such a reduction. Returning to the currently available

TABLE III-Results of randomised controlled trials of diuretics on perinatal deaths, stillbirths, and neonatal deaths

\begin{tabular}{|c|c|c|c|c|c|c|c|c|c|c|c|c|c|c|}
\hline \multirow{3}{*}{ Study } & \multicolumn{2}{|c|}{$\begin{array}{l}\text { No of patients } \\
\text { followed up }\end{array}$} & \multicolumn{4}{|c|}{ Perinatal deaths } & \multicolumn{4}{|c|}{ Stillbirths } & \multicolumn{4}{|c|}{ Neonatal deaths } \\
\hline & \multirow{2}{*}{ Treated } & \multirow{2}{*}{ Control } & \multirow{2}{*}{$\begin{array}{l}\text { No in } \\
\text { treated } \\
\text { patients }\end{array}$} & \multirow{2}{*}{$\begin{array}{l}\text { No in } \\
\text { controls }\end{array}$} & \multicolumn{2}{|c|}{ Treated patients } & \multirow{2}{*}{$\begin{array}{l}\text { No in } \\
\text { treated } \\
\text { patients }\end{array}$} & \multirow{2}{*}{$\begin{array}{l}\text { No in } \\
\text { controls }\end{array}$} & \multicolumn{2}{|c|}{ Treated patients } & \multirow{2}{*}{$\begin{array}{l}\text { No in } \\
\text { treated } \\
\text { patients }\end{array}$} & \multirow{2}{*}{$\begin{array}{l}\text { No in } \\
\text { controls }\end{array}$} & \multicolumn{2}{|c|}{ Treated patients } \\
\hline & & & & & $\mathrm{O}-\mathrm{E}^{*}$ & $\overline{\text { Variance }}$ & & & O-E* & Variance & & & O-E* & Variance \\
\hline $\begin{array}{l}\text { Weseley and Douglas } \\
\text { Flowers et } \text { al }^{3} \\
\text { Menzies } \\
\text { Fallis } e t \text { al }^{5} \\
\text { Cuadros and Tatum } \\
\text { Landesman } \text { et }^{6} l^{7} \\
\text { Kraus } e t \text { al } \\
\text { Tervila and Vartiainen }{ }^{10} \\
\text { Campbell and MacGillivray }{ }^{1112}\end{array}$ & $\begin{array}{r}131 \\
335 \\
57 \\
34 \\
1011 \\
1370 \\
506 \\
108 \\
153\end{array}$ & $\begin{array}{r}136 \\
110 \\
48 \\
40 \\
760 \\
1336 \\
524 \\
103 \\
102\end{array}$ & $\begin{array}{r}1 \\
6 \\
3 \\
1 \\
14 \\
24 \\
14 \\
0 \\
0\end{array}$ & $\begin{array}{r}4 \\
3 \\
2 \\
3 \\
13 \\
19 \\
16 \\
0 \\
0\end{array}$ & $\begin{array}{l}-1.5 \\
-0.8 \\
+0.3 \\
-0.8 \\
-1.4 \\
+2.2 \\
-0.7 \\
0 \\
0\end{array}$ & $\begin{array}{l}1 \cdot 2 \\
1.6 \\
1 \cdot 2 \\
1 \cdot 0 \\
6 \cdot 5 \\
10 \cdot 6 \\
7 \cdot 3 \\
0 \\
0\end{array}$ & $\begin{array}{l}1 \\
3 \\
1 \\
0 \\
6 \\
6 \\
0 \\
0\end{array}$ & $\begin{array}{l}2 \\
2 \\
1 \\
1 \\
5 \\
\text { Not av } \\
9 \\
0 \\
0\end{array}$ & $\begin{array}{l}-0.5 \\
-0.8 \\
-0.1 \\
-0.5 \\
-0.3 \\
\text { railable } \\
-1.4 \\
0 \\
0\end{array}$ & $\begin{array}{l}0 \cdot 7 \\
0 \cdot 9 \\
0 \cdot 5 \\
0 \cdot 3 \\
2 \cdot 7 \\
3 \cdot 7 \\
0 \\
0\end{array}$ & $\begin{array}{l}0 \\
3 \\
2 \\
1 \\
8\end{array}$ & $\begin{array}{c}2 \\
1 \\
1 \\
2 \\
8 \\
\text { Not av } \\
7 \\
0 \\
0\end{array}$ & $\begin{array}{c}-1.0 \\
0 \\
+0.4 \\
-0.4 \\
-1.1 \\
\text { ailable } \\
+0.6 \\
0 \\
0\end{array}$ & $\begin{array}{l}0.5 \\
0.7 \\
0.7 \\
0.7 \\
3.9 \\
\\
3.7 \\
0 \\
0\end{array}$ \\
\hline $\begin{array}{l}\text { Overall: } \\
\text { Perinatal deaths }\end{array}$ & 3705 & 3159 & \multirow{2}{*}{$\begin{array}{c}63 \\
(1.7 \%)\end{array}$} & \multirow{2}{*}{$\begin{array}{c}60 \\
(1.9 \%)\end{array}$} & $-2 \cdot 7$ & $29 \cdot 4$ & & & & & & & & \\
\hline \multirow[t]{2}{*}{ Stillbirths and neonatal deaths } & 2335 & 1823 & & & & & $\begin{array}{c}17 \\
(0 \cdot 7 \%)\end{array}$ & $\begin{array}{c}20 \\
(1 \cdot 1 \%)\end{array}$ & $-3 \cdot 4$ & $8 \cdot 8$ & $\begin{array}{c}22 \\
(0.9 \%)\end{array}$ & $\begin{array}{c}21 \\
(1 \cdot 2 \%)\end{array}$ & -1.5 & $10 \cdot 3$ \\
\hline & & & \multicolumn{3}{|c|}{ "Pooled" relative risk } & \multicolumn{3}{|c|}{$95 \%$ confidence interval } & \multicolumn{4}{|c|}{ Test for heterogeneity } & & \\
\hline $\begin{array}{l}\text { Perinatal deaths } \\
\text { Stillbirths } \\
\text { Neonatal deaths }\end{array}$ & & & \multicolumn{3}{|c|}{$\begin{array}{l}0.91 \\
0.68 \\
0.86\end{array}$} & \multicolumn{3}{|c|}{$\begin{array}{l}0.64,1.31 \text { (NS) } \\
0.35,1.31 \text { (NS) } \\
0.47,1.59 \text { (NS) }\end{array}$} & \multicolumn{4}{|c|}{$\begin{array}{l}\chi^{2}{ }_{8}=3.5 \text { (NS) } \\
\chi_{7}^{2}=1.0 \text { (NS) } \\
\chi^{2}{ }_{7}=2.5 \text { (NS) }\end{array}$} & & \\
\hline
\end{tabular}

*The number of patients allocated to treatment who were observed to develop a particular unfavourable event minus the number that would have been expected to do so if treatment had no effect. 
data, however, at least the favourable direction of the results on stillbirth does not support the fears that diuretics may be seriously harmful to the fetus.

\section{SIDE EFFECTS}

As various workers have expressed concern, based on inadequately controlled case reports, that diuretics may have adverse effects in pregnancy, particularly by causing neonatal thrombocytopenia and jaundice and maternal pancreatitis, hypokalaemia, and hyponatraemia, ${ }^{91019-28}$ we tabulated the incidence of these side effects in those randomised controlled trials in which they were reported (table IV). ${ }^{346}$ 79-12 $^{24}$ There was no significant excess of neonatal thrombocytopenic purpura or jaundice, and no cases of maternal pancreatitis had been reported. Likewise, a significant difference in the incidence of maternal hyponatraemia or hypokalaemia was not reported in most trials, although two trials, which did not use potassium supplementation, did report an increased incidence of hypokalaemia. ${ }^{910}$ These cases, however, rarely caused any problems. The data suggested that the reported risks of serious side effects of diuretic treatment, which must have contributed to its decreasing popularity, may have been overstated and perhaps have been due, at least in part, to selected case reporting.

\section{Discussion}

This overview raises two main questions. Firstly, does such an overview have any real medical relevance or is it merely an empty (or even potentially misleading) statistical exercise? We have discussed above various possible difficulties, and our view is that, as long as the precautions discussed there are adopted, the dangers of attempting such an overview are far less than the dangers of not doing so. Clinical trials often require surprisingly large numbers of participants to show unequivocally even clinically important differences between treated and control patients. The difficulty is increased when the end point is rare (pre-eclampsia, which is severe in only about one fifth of cases, occurs in only about a quarter of pregnancies, ${ }^{17}$ and stillbirths, which are thought to be secondary to pre-eclampsia in only about one quarter of cases, ${ }^{30}$ occur in less than $1 \%{ }^{18}$ ). The difficulty is increased still further when, as is commonly the case, even a treatment that produces a worthwhile benefit is likely to reduce the incidence of the end point only moderately-for example, by 10,20 , or $30 \%$-rather than by a large amountfor example, by over $50 \%$. When, in these circumstances, trials of inadequate size do not achieve significant results they are often misinterpreted as showing that treatment has no effect (as has occurred in the case of diuretics) when, in fact, the trials are not powerful enough to distinguish between absence of benefit and moderate benefit. Not surprisingly, therefore, a large number of small trials may lead to conflicting results due to the play of chance, whether or not there is really any important heterogeneity of treatment effect.

Secondly, what are the implications for future trials of perinatal treatment with diuretics, $\beta$ blockers, or other agents ? Clearly, from the large number of studies with diuretics performed over 15 years, their inadequate size has resulted in a long controversy. Yet, what practical lessons about the conduct of trials have been learnt from all this ? Despite the difficulties in interpreting trials of inadequate size, two recent studies of newer agents ( $\beta$ blockers) in pregnancy randomised only 100 and 120 patients respectively. ${ }^{31}{ }^{32}$ Not surprisingly, they reached opposite conclusions; indeed, one of them actually concluded that there was no significant difference in fetal outcome, although no stillbirths occurred in either treatment group. ${ }^{31}$ The lessons of the failure to evaluate diuretics properly must be understood and acted on so that trials of future agents are large enough to be of serious scientific value in assessing the effects of treatment on perinatal mortality. Such trials may, except when patients at peculiarly high risk can be identified, have to include many thousands, perhaps even tens of thousands, of patients. This can be achieved in practice only by extraordinarily wide collaboration, which in turn probably requires the trial to entail extraordinarily little extra work per patient. If the chief end point is perinatal mortality, whether the effects of treatment on such variables as blood pressure, oedema, or proteinuria-or any other routine clinical observations for that matter-are reported to the trial centre simply does not matter. Depending on the agent or agents being tested, no, or at most very little, extra follow-up or record keeping may be needed over and above ordinary clinical practice. Fortunately, therefore, the conduct of such a trial could be extraordinarily simple, imposing no great burdens on the trial centre or the collaborators in the trial. (The only exception is that, as there are many different modes of perinatal death, only some of which are associated with preeclampsia, an effort would have to be made to put the modes of death into subcategories at least to the extent that is rendered possible by retrospective examination of routine records.)

Thus, in trials in which the chief end points are events like perinatal death that are readily assessed from routine records, there is often no need for any appreciable extra work by prospective participants. Unless this fortunate circumstance is exploited to the full, the current and future trials of agents such as $\beta$ blockers may be as uninformative about perinatal mortality as the trials of diuretics have been. This would be unfortunate, for during the decades while 10000 patients were being randomised into trials of diuretics, a vast number (perhaps several millions) of pregnant women were treated in an uncontrolled way with these agents. In view of the commercial pressures to use $\beta$ blockers, their unevaluated, uncontrolled use could become at least as widespread as that of diuretics, in which case it might be a prudent, rather than a disproportionate, use of resources to randomise some tens of thousands of patients to discover whether $\beta$ blockers are of any material value. More generally, the same should apply to any other medical treatments that might come into widespread use.

We thank Dr D Campbell, Dr T Ferris, Dr F Finnerty, Dr C Flowers, Dr R Landesman, Dr H Langford, Dr D Menzies, Dr L Tervila, Dr A Weseley, Dr S Yen, and Dr F Zuspan for providing additional details about their studies; Iain Chalmers for his advice and encouragement; and Gale Mead for typing and retyping the manuscript.

\section{Appendix}

If treatment moderately reduced the odds of a particular unfavourable outcome occurring to a roughly similar extent in all trials the grand total and its variance might in addition be used to calculate a "pooled" odds ratio $(P O R=\exp (\mathrm{GT} / \mathrm{VT})$ ). This is a useful estimate of the ratio of the odds of an unfavourable outcome among the patients allocated to treatment to that among the controls, with approximate $95 \%$ confidence limits $(\exp (\mathrm{GT} / \mathrm{VT} \pm 1.96 / \sqrt{\mathrm{VT}}))$. Because in these trials very few adverse outcomes were observed we have (somewhat loosely) referred to these "pooled" odds ratios as pooled relative risks. The assumption that the true effects in each trial might have been similar, but for the play of chance, can be tested by an approximately " $\chi{ }^{2}$ " test $\left(\chi^{2}\right.$ for heterogeneity $\simeq$ the sum, for all $\mathrm{k}$ trials with non-zero variance, of $(\mathrm{O}-\mathrm{E})^{2} / \mathrm{V}$ minus $\mathrm{GT}^{2} / \mathrm{VT}$, with degrees of freedom $=k-1)$. In practice, of course, for important end points (such as perinatal death), it is difficult to obtain enough data to be able to decide reliably whether any net good or harm results from treatment and even more difficult to obtain enough data to estimate reliably the size of any such benefits, even from an overview of many trials. Consequently, the above statistical details can, for most practical purposes, be ignored: what chiefly matters is the simple question of whether there was clear evidence of any net effect of treatment.

\section{References}

1 Zuspan FP, Bell JD, Barnes AC. Balance ward and double-blind diuretic studies during pregnancy. Obstet Gynecol 1960;16:543-9. 
2 Weseley AC, Douglas GW. Continuous use of chlorothiazide for prevention of toxemia of pregnancy. Obstet Gynecol 1962;19:355-8

WE, Bonner OB. Chlorothiazide as a prophylaxis against toxe

4 Menzies DN Controlled trial of chlorothiazide in treatment of early pre-eclampsia.

$B r$ Med $\mathcal{F} 1964 ; \mathrm{i}: 739-42$.
5 Fallis NE, Plauche WC, Mosey LM, Langford HG. Thiazide versus placebo in prophylaxis of toxemia of pregnancy in primigravid patients. Am $\mathcal{f}$ Obste Gynecol 1964;88:502-4.

6 Cuadros A, Tatum HJ. The prophylactic and therapeutic use of bendroflume-

7 thiazide in pregnancy. Am $\mathcal{f}$ Obstet Gynecol 1964;89:891-7. The prophylactic use of chlorthalidone, a sulfonamide diuretic, in pregnancy.

8 Finnerty FA Jr, Bepko FJ Jr. Lowering the perinatal mortality and the prematurity rate. The value prophylactic thiazides in juveniles. F $A M A 1966$ 195: $135-8$

9 Kraus GW, Marchese JR, Yen SSC. Prophylactic use of hydrochlorothiazide in pregnancy, fAMA 1966;198:128-32.

Tervila $L$, Vartiainen $E$. The effects and side effects of diuretics in the prophylaxis

11 Campbell DM, MacGillivray I. The effect of a low calorie diet or a thiazide diuretic on the incidence of pre-eclampsia and on birth weight. $\mathrm{Br} \mathcal{F}$ Obstet Gynaecol 1975;82:572-7.

12 MacGillivray I, Campbell DM. The relevance of hypertension and oedema in pregnancy. Clin Exp Hypertens 1980;2:897-914.

13 Redman CWG. Treatment of hypertension in pregnancy. Kidney Int 1980;18: 267-78.

14 MacGillivray I. Sodium and water balance in pregnancy hypertension-the role Gray MJ. Use and abuse of thiazides in pregnancy. Clin Obstet Gynecol 1968;11 $568-78$

16 Lindheimer MD, Katz AI. Sodium and diuretics in pregnancy. Obstet Gynecol $1974 ; 44: 434-40$.

Chamberlain G, Phillip E, Howlett B, Masters K. British births. London: Heinemann, 1970 .

18 Office of Population Censuses and Surveys Monitor. Infant and perinatal mortality 1981. London: Office of Population Censuses and Surveys, 1982.

19 Pritchard JA, Walley PJ. Severe hypokalemia due to prolonged administration of chlorothiazide during pregnancy. Am $\mathcal{F}$ Obstet Gynecol $1961 ; 81: 1241-4$.
20 Goldman JA, Neri A, Ovadia J, Eckerling B, De Vries A. Effect of chlorothiazide on intravenous glucose tolerance in pregnancy. Am $\mathcal{F}$ Obstet Gynecol 1969;

21 Ferris TF. Toxemia and hypertension. In: Burrow GN, Ferris TF, eds. Medical complications during pregnancy. 2nd ed. Philadelphia: WB Saunders, 1975:53-

22 Harley JD, Robin $\mathrm{H}$, Robertson SEJ. Thiazide-induced neonatal haemolysis. Med f 1964 ; : $: 696-7$.

23 Rodriguez SU, Leikin SL, Hiller MC. Neonatal thrombocytopenia associated with ante.

24 Crosland DM, Flowers CE Jr. Chlorothiazide and its relationship to neonatal jaundice. Obstet Gynecol 1963;22:500-4.

25 Minkowitz S, Soloway HB, Hall JE, Yermakov V. Fatal hemorrhagic pancreatitis following chlorothiazide administration in pregnancy. Obstet Gynecol 1964;

26 Johnston $\mathrm{DH}$, Cornish $\mathrm{AL}$. Acute pancreatitis in patients receiving chlorothiazide. f $A M A$ 1959;170:2054-6.

27 Menzies D, Prystowsky H. Acute hemorrhagic pancreatitis during pregnancy and the puerperium associated with thiazide therapy. $\mathcal{F}$ Fla Med Assoc 1967; and the pue

28 Miller JN. Hyponatremia: a complication of the treatment of the edema of pregnancy. Obstet Gynecol 1960;16:587-90.

29 Peto R, Pike MC, Armitage P, et al. Design and analysis of randomized clinical trials requiring prolonged observation of each patient. 1. Introduction and

design. Br 7 Cancer 1976;34:585-612.
30 McIlwaine GM, Dunn F, Howat RCL, Smalls M, Wyllie MM, Macnaughton MC. The Scottish perinatal mortality survey 1977-1981. Glasgow: University of Glasgow, 1984

31 Fidler J, Smith V, Fayers $P$, De Swiet $M$. Randomised controlled comparative study of methyldopa and oxprenolol in treatment of hypertension in pregnancy. Br Med F 1983;286:1927-30.

Clark Dumer DJ, Low RA, Butters L, Reynolds B. Placebocontrolled trial of atenolol in treatment of pregnancy-associated hypertension. Lancet $1983 ; \mathrm{i}: 431-4$.

33 Chesley LC. The remote prognostic significance of the level of blood pressure in

pregnancy. Clin Exp Hypertens 1980;2:777-801.
34 Nelson TR. A clinical study of pre-eclampsia. I. Br $\mathcal{F}$ Obstet Gynaecol 1955;62:

(Accepted 21 November 1984)

\title{
Clinical importance of enteric communication with abdominal abscesses
}

\author{
S H SAVERYMUTTU, A M PETERS, J P LAVENDER
}

\begin{abstract}
The dynamics of leucocytes in abdominal abscesses were studied using indium-111 autologous leucocyte scanning in 30 patients. Thirteen patients showing enteric drainage of leucocytes on delayed scans were characterised by a lack of abdominal localising signs and a low detection rate by ultrasound ( $25 \%)$. By contrast, 16 of 17 patients without enteric drainage had abdominal signs, and in these patients ultrasound was associated with a higher detection rate $(58 \%)$. Despite the presence of an enteric route of drainage for the abscess 10 of the 13 patients needed surgical intervention.

These results help explain the wide variation in clinical presentation of abdominal abscesses; suggest that ${ }^{111}$ In leucocyte scanning should be the initial investigation in those patients without focal signs; and show that formal surgical drainage is needed in patients recognised as having enteric communication with abscesses.
\end{abstract}

\section{Introduction}

Despite advances in surgical technique and medical treatment intra-abdominal abscesses remain a common diagnostic problem. Mortality is over $80 \%$ in undrained collections ${ }^{12}$ but may be decreased to less than $30 \%$ with effective surgical treatment. The critical factor determining the prognosis of these patients is the difficulty in localising the abscesses. In many abscesses there are classic clinical features with focal abdominal tenderness, and in these cases ultrasound is a rapid, sensitive diagnostic technique. ${ }^{3}{ }^{4}$ In some abscesses, however, the clinical presentation may be insidious with minimal signs of localisation, and these pose much greater problems in diagnosis. This wide range in clinical presentation of intraabdominal abscesses is unexplained.

During early studies using indium-111 leucocyte scanning we observed that in some abscesses with minimal localising signs there was drainage of labelled leucocytes into the bowel on delayed scans, indicating enteric communication with the abscesses. ${ }^{5}$ To investigate whether enteric drainage of pus decompresses the abscess and so accounts for lack of abdominal signs we have examined the incidence of enteric communication with abscesses and related this feature to the clinical presentation.

\section{Patients and methods}

From August 1981 to December 1983 patients referred to this hospital's department of diagnostic radiology for routine ${ }^{111}$ In leucocyte scans were included in the study if $(a)$ an abscess was detected by the scan, $(b)$ the diagnosis was confirmed independently, and $(c)$ full clinical details were available for review.

A total of 30 abscesses were studied. Confirmation of the diagnosis
$S$ H SAVERYMUTTU, BSC, MRCP, lecturer in medicine

A M PETERS, $M D$, senior lecturer in radiology

Correspondence to: Dr S H Saverymuttu, Medicine II, St George's Hospital Medical School, Tooting, London SW 17 . 